\title{
Varied Virological Response of Patients with Chronic Hepatitis C against the Treatment of Pegylated Interferon- $\alpha$ and Ribavirin
}

\author{
Neha Tabassum ${ }^{1}$, Zeba Raheem ${ }^{1}$, Anwar Yasmin ${ }^{1}$, Mohammed Nomaan Ilyas ${ }^{1}$, \\ Arshad Hussain Mohd ${ }^{1}$, Raju Nagarapu ${ }^{2}$, Sandeep K Vishwakarma ${ }^{2}$, Avinash \\ Bardia $^{2}$, Syed Rahamathulla ${ }^{2}$, Mohd. Aejaz Habeeb ${ }^{2}$, Aleem Ahmed Khan ${ }^{2 \& 3^{*}}$ \\ 1. Department of Pharmacy Practice, Pharm D, Deccan School of Pharmacy, Hyderabad-500 001, AP, India. \\ 2. Center for Liver Research and Diagnostics, Deccan College of Medical Sciences and Allied Hospitals, \\ Kanchanbagh, Hyderabad-500 058, AP, INDIA. \\ 3. Salar-E-Millat Sultan Salahuddin Owaisi Centre for Cellular and Molecular Medicine, Princess Esra \\ Hospital, Hyderabad, AP, India.
}

*Corresponding Address: Dr. Aleem Ahmed Khan, Associate Professor, Center for Liver Research and Diagnostics, Deccan College of Medical Sciences and Allied Hospitals, Kanchanbagh, Hyderabad-500 058, Andhra Pradesh, INDIA. Ph/Fax: +91-040-24342954,E-mail: aleem_a_khan@rediffmail.com

\begin{abstract}
INTRODUCTION : Hepatitis C Virus (HCV) is the leading cause of death throughout the world. The standard of care for the treatment of chronic hepatitis $C$ is combination therapy with Pegylated Interferon (PEG-IFNa 2a) and Ribavirin (RBV). There currently exists no systematic explanation for these genotypespecific differences in clinical outcome. Furthermore, whether factors that govern outcome for one genotype play a similar role in other genotype remains to be fully explored. Hence, the present study was taken in consideration of the factors emphasizing their impact on the sustained virological response (SVR) against HCV genotypes.
\end{abstract}

METHODOLOGY : A total of 50 patients (Age, Mean: $\pm S D 42.53 \pm 12.6)$ having chronic hepatitis $C$ genotype 3 and genotype 1 who showed positive result for HCV-RNA for more than 6 months were treated with

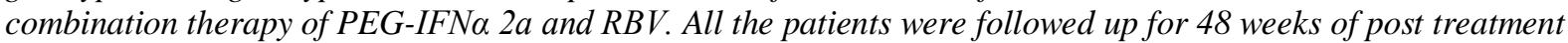
and varied virological response was recorded in respect to the HCV genotypes, subtypes and biological parameters.

RESULTS : In present study, we have observed that males had a better SVR and EVR as compared to females in both the genotypes (genotype 1 and genotype 3) and among the non responders there were less males as compared to females. It was also seen that there were less females who showed EVR and SVR as compared to males.

CONCLUSION : Our study has demonstrated that EVR, RVR, NR and most importantly SVR are important factors for the achievement of complete virological response against HCV genotypes and subtypes.

KEYWORDS : Virological response, HCV, Pegylated Interferon- $\alpha$ and Ribavirin

\section{INTRODUCTION}

Nearly 170 million people worldwide are chronically infected with HCV [1]. In the United State, HCV is the leading cause of hepatocellular carcinoma and the leading indication for liver transplantation [2].The standard of care for the treatment of chronic hepatitis $\mathrm{C}$ is combination therapy with PEG-IFN $\alpha 2 \mathrm{a}$ and RBV. PEG-IFN is a synthetic variant of interferon- $\alpha$ (a naturally occurring cytokine) whose endogenous role is to activate the innate immune response within the host. Injected PEG-IFN is hypothesized to function by mimicking the natural cytokines. RBV is a nucleoside analog and is thought to act through a combination of other modalities [3, 4]. PEG-IFNa2a offers significantly enhanced SVR in all patients, regardless to HCV genotype and viral load. The ability to predict the absence of SVR against HCV at molecular level will be a useful clinical tool. The combination therapy with Peg-IFNa $2 \mathrm{a}$ and RBV provides a considerable clinical advantage over conventional therapy [21]. Large clinical trials of PEG-IFN/RBV therapy have revealed significantly different response rates for the various HCV genotypes. 
There are six major HCV genotypes, named genotype 1 to 6 in which genotype 2 has been showed the most responsive with a SVR rate of $>80 \%$. Studies have also suggested that it is reasonable to treat some patients infected with this genotype for only 12-16 weeks. Conversely, the most prevalent genotype worldwide, genotype 1 is the least responsive [5, 6, 7]. The SVR for patients infected with genotype 1 is less than $50 \%$. Current guidelines recommend 48 weeks of therapy for this particular genotype; shorter courses of therapy have been demonstrated to be sub-optimal [8]. There currently exists no systematic explanation for these genotypespecific differences in clinical outcome $[4,9,10]$. It is assumed that genotype-specific clinical response rate is the result of a confluence of host and viral factors and remains a challenging area for further promising investigations. Furthermore, whether factors that govern outcome for one genotype play a similar role in other genotype remains to be fully explored. Based on the genotype variability, viral load, IFN $\alpha$ dose, and the treatment duration, SVR rate upto 55\% has been achieved in patients with $\mathrm{HCV}$ other than the HCV genotypes 1 [11]. Whereas, SVR rate of $38 \%$ to $67 \%$ had been achieved in patients with genotype 3 based on the dose of IFN $\alpha[12,13]$. Various comparative study results as per the existing biomedical literature available on IFN $\alpha$ monotherapy versus PEG-IFN $\alpha$ shows a SVR rate of $24 \%$ to $46 \%$ and $38 \%$ to $68 \%$ respectively $[14,15]$. Furthermore, biomedical researchers have compared the efficacy of the combination therapy of PEG-IFN $\alpha$ dose of 3 million units three times per week. SVR rate of patients with HCV genotype 3 were $21 \%$ to $32 \%[16,17]$ for IFN $\alpha$ and $38 \%$ to $45 \%$ for PEG-IFN $\alpha[15,18]$. In subtypes of HCV genotype 3 patients with low baseline viral load have showed almost 58\% of SVR those who were treated with PEG-IFNa [18]. However, currently the standard treatment for patients with HCV genotype 3 is a combination therapy of PEG-IFN $\alpha$ and RBV for 24 weeks attaining SVR rates of upto 80\% [19] and for 48 weeks in genotype 1 patients attaining SVR of $40 \%$ to 50\% [19]. Patients with HCV genotype 3 and 1 were treated with a schedule (RBV-600mg/day or 1000$1200 \mathrm{mg} /$ day i.e, $.1 .5 \mathrm{mg} / \mathrm{kg}$ bogy weight $)$ and PEG-IFN $\alpha 2 \mathrm{a}$ at a dose of $180 \mathrm{mcg}(15 \mathrm{mg} / \mathrm{kg}$ body weight $)$ as per the guidelines of National Institute for Clinical Health and Excellence.

Since the combination therapy with RBV increases the rate of side effects, the discontinuation rate is more frequent and patient's haemoglobin concentration decreases. Independent prognostic factors for SVR include the viral load, viral genotype, absence of cirrhosis or fibrosis, age and gender. There remains a probability that the SVR rates could be influenced by considering these prognostic factors. Hence, the present study was taken in consideration of all the above factors emphasizing their impact on the SVR against HCV genotype 1 and genotype 3 .

\subsection{Patient's selection}

\section{MATERIALS AND METHODS}

A total of 50 patients (age, Mean \pm SD: $42.53 \pm 12.6$ ) attending the centre (from January 1994 to December 2010) having chronic hepatitis C genotype 3 and genotype 1 who showed positive result for HCVRNA for more than 6 months were treated. All of them were treated with combination therapy of PEG-IFN $\alpha$ a and RBV. Chronicity was receorded by the longitudinal observation and presence of advanced clinical liver disease in patients who refused to undergo liver biopsy (Fig. 1).

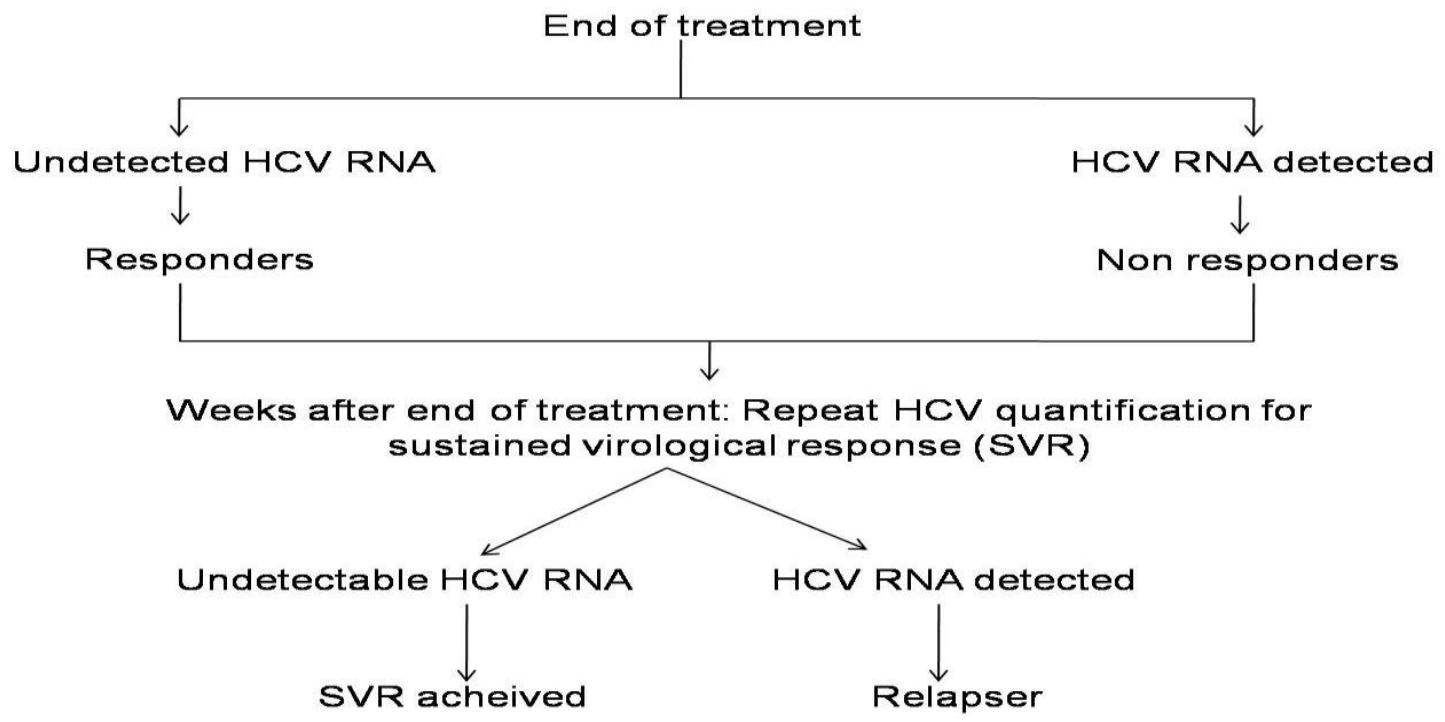

Fig. 1: Study design for SVR against HCV genotypes and subtypes using demographical, clinical and molecular parameters 
Following inclusion criteria's were taken in account for screening of the subjects:

a) patients with chronic Hepatitis $\mathrm{C}$ by clinical criteria and/or histopathology,

b) patients with positive HCV-antibody and positive HCV-RNA, and

c) Patients with HCV genotype 3 and genotype 1 infection.

The patients with decompensated liver diseases, improperly controlled diabetes, active auto immune disorders, alcohol or intravenous drug abusers, high levels of serum alpha-feto protein concentration, past history of psychiatric illness, anemia, thrombocytopenis, and pregnancy excluded from the study. Further, the patients with Hepatitis A Virus (HAV) in active form, Human Immunodeficiency Virus (HIV), Hepatitis B Virus (HBV), cytomegalovirus (CMV) or Epstein-Barr virus (EBV) infection were also excluded. The study was based and conformed upon the ethical guidelines of 1975 declaration of Helenski and was approved by the Institutional Ethics Committee of Deccan College of Medical Sciences, Hyderabad. Before collection of the samples all the patients were informed well and written informed consent was taken.

\subsection{Detection of serum HCV-specific RNA by RT-PCR}

The extraction of viral RNA from serum samples was done using QIAamp Viral RNA Kit (Qiagen, Germany) according to the manufacturer's instructions. Complementary deoxyribonucleic acid (cDNA) was prepared using viral RNA specific reverse primer and reverse transcriptase II (Fermentas, Burlington, Canada). 5ng of cDNA was used for reverse transcription quantitative polymerase chain reaction (RT-qPCR) analysis using Taqman chemistry in StepOne Real-Time PCR (Applied Biosystems, CA, USA).

\subsection{Determination of $\mathrm{HCV}$ genotypes and subtypes}

The samples tested positive for HCV RNA, genotyping and subtyping was done by Innolipa HCV II line probe assay (Innogenetics, Ghent, Belgium).

\subsection{Treatment regimen}

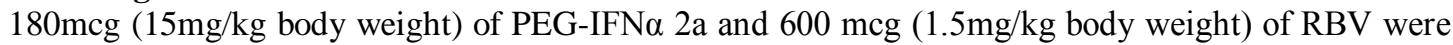
given to the patient once a week for about 24-48 weeks as per the dose approved by Roferon-A, F. Hoffmann-La Roche, Basel, Switzerland. Then after the period of 24-48 weeks therapy, the end of treatment (EOT) was used to define the SVR against HCV infection.

\subsection{Monitoring of the patients}

The patients were observed at $2^{\text {nd }}, 4^{\text {th }}, 6^{\text {th }}$ and $8^{\text {th }}$ weeks of their treatment at an outpatient setting and then every $4^{\text {th }}$ week thereafter during the treatment. After the EOT, the follow-up assessments were made at every $24^{\text {th }}$ and $48^{\text {th }}$ week. At each assessment session, the clinical examinations like blood cell counts and routine biochemical tests were performed. Laboratory values were normalized by dividing their measurement by the upper limit of normal value used as a continuous variable. At time zero and week $2^{\text {nd }}, 4^{\text {th }}, 12^{\text {th }}, 24^{\text {th }}, 36^{\text {th }}$ and $48^{\text {th }}$ during the course of treatment, the HCV-RNA by RT-PCR was assessed. The presence of HCV-RNA in serum was checked at week 24 and 48 after the EOT during the period of follow-up.

\subsection{Evaluation of biochemical parameters with reverence to the treatment}

Histological and biochemical parameters were taken into consideration for the evaluation of treatment response in the patients. Various parameters which were considered were ALT, AST, ALP, WBC and platelet count. The traditional marker for assessing treatment response is normalization of the serum ALT level. Although this endpoint was established before identification of the $\mathrm{HCV}$, it appears to be appropriate as measuring HCV-RNA for determining the initial response to interferon, i.e. normalization of ALT is usually associated with loss of detectable virus from the serum.

\section{STATISTICAL ANALYSIS}

All the data of the study were calculated as mean and standard deviation. Continuous and categorical variables were compared using Wilcoxon Mann Whitney U test and Fisher's exact test using the link http://ing.gsf.de/cgi-bin/hw/hwl.pl. The p value was calculated using the Student's $t$ test and the statistical analyses were done using the statistic program link

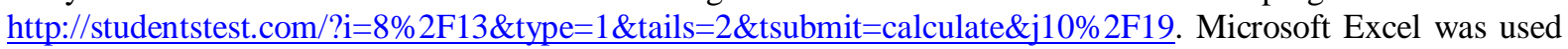
to generate the graphical data for SVR against HCV genotypes and subtypes. P $\leq 0.05 \%$ was considered to be significant. 


\subsection{Demographic and clinical properties}

\section{RESULTS}

Out of total 50 enrolled subjects, 32 males and 18 female patients received treatment. The clinical profile of all the patients comprising of 50 patients with a mean age of 42.53, the route of $\mathrm{HCV}$ infection and the method of detection is summarized in table 1 .

Table 1: Demographic and clinical features of the subjects enrolled in the study

\begin{tabular}{|lc|}
\hline \multicolumn{1}{|c|}{ Parameters } & Value No. (\%) \\
\hline No. of patients & 50 \\
Age Y (Mean \pm SD) & $42.53 \pm 12.6$ \\
Sex (no. of patients/\%) & \\
Female & $18[36 \%]$ \\
Male & $32[64 \%]$ \\
Route of infection (no. of patients/\%) & \\
Accidental needle prick & $4[8 \%]$ \\
Unhygienic habits & $6[12 \%]$ \\
Blood transfusion & $12[24 \%]$ \\
Surgery & $8[16 \%]$ \\
Unsterilized Needles & $8[16 \%]$ \\
Unknown & $12[24 \%]$ \\
Mode of detection (no. of patients) & 50 \\
ELISA & 50 \\
PCR &
\end{tabular}

\subsection{Virological response stratified by treatment group and genotype}

The standard therapy (PEG-IFN $\alpha 2 \mathrm{a}$ and RBV) was given to all the patients and it was found that 6 out of 50 patients did not respond at all out of which 2 were males and 4 were females. We also observed that the non responders in case of genotype 1a were 3 ( 1 male and 2 females) and for genotype $1 \mathrm{~b}$ were 2 ( 1 male and 1 female). In case of genotype $3 \mathrm{a}$, there was only 1 non responder (female) and for genotype $3 \mathrm{~b}$ there were no non responders. So we concluded that the response rate in case of genotype 3 ( $3 \mathrm{a}$ and $3 \mathrm{~b}$ ) was higher as compared to genotype 1 (1a and 1b) (Table 2).

Table 2: Virological response stratified by the treatment group against HCV subtypes

\begin{tabular}{|c|c|c|c|c|c|c|c|}
\hline \multirow[t]{2}{*}{ Genotype } & \multicolumn{2}{|c|}{ EVR } & \multicolumn{2}{|c|}{ SVR } & \multicolumn{2}{|c|}{ NR } & \multirow[t]{2}{*}{ Total } \\
\hline & $\mathbf{M}$ & $\mathbf{F}$ & $M$ & $\mathbf{F}$ & M & $\mathbf{F}$ & \\
\hline $1 \mathrm{a}$ & 1 & 1 & 3 & 2 & 1 & 2 & 10 \\
\hline 1b & 1 & 0 & 5 & 3 & 1 & 1 & 11 \\
\hline $3 \mathbf{a}$ & 2 & 1 & 8 & 6 & 0 & 1 & 18 \\
\hline 3b & 2 & 2 & 6 & 1 & 0 & $0>$ & 11 \\
\hline Total & 6 & 4 & 22 & 12 & 2 & 4 & 50 \\
\hline
\end{tabular}

When analyzing the virological response in patients undergoing for the treatment were found that the patient's who continued to experience a sharp decline in viral load during the first 4-12 weeks of treatment had greater chance of achieving the SVR. 
We found that 10 out of 50 patients showed EVR, out of which 6 were males and 4 were females, 2 patients who showed EVR in genotype 1a (one male and one female) and one patient who showed EVR in genotype $1 \mathrm{~b}$ (one male). There were 3 patients under genotype $3 \mathrm{a}$ that showed EVR ( 2 males and 1 female) and 4 patients showed EVR in genotype $3 b$ ( 2 males and 2 females). Hence patients with genotype 3 ( $3 a$ and $3 b$ ) showed a better EVR as compared to the genotype 1(1a and 1b).34 out of 50 patients showed SVR out of which 22 were males and 12 were females. Under genotype 1a, 5 patients showed SVR ( 3 males and 2 females). Under genotype $1 \mathrm{~b}, 8$ patients showed SVR ( 5 males and 3 females). Under genotype $3 \mathrm{a}, 14$ patients showed SVR ( 8 males and 6 females). Under genotype 3b, 7 patients showed SVR (6 males and 1 female). Hence, the SVR in case of genotype 3(3a and $3 b)$ was more and in case of genotype 1(1a and $1 b)$ was less. Hence, patients with genotype 3 ( $3 a$ and $3 b$ ) have showed more SVR, better EVR and there were less non responders (NR) in them as compared to patients with genotype 1(1a and $1 \mathrm{~b}$ ) which showed less EVR, less SVR and more non responders (NR) (Fig. 2a and 2b).

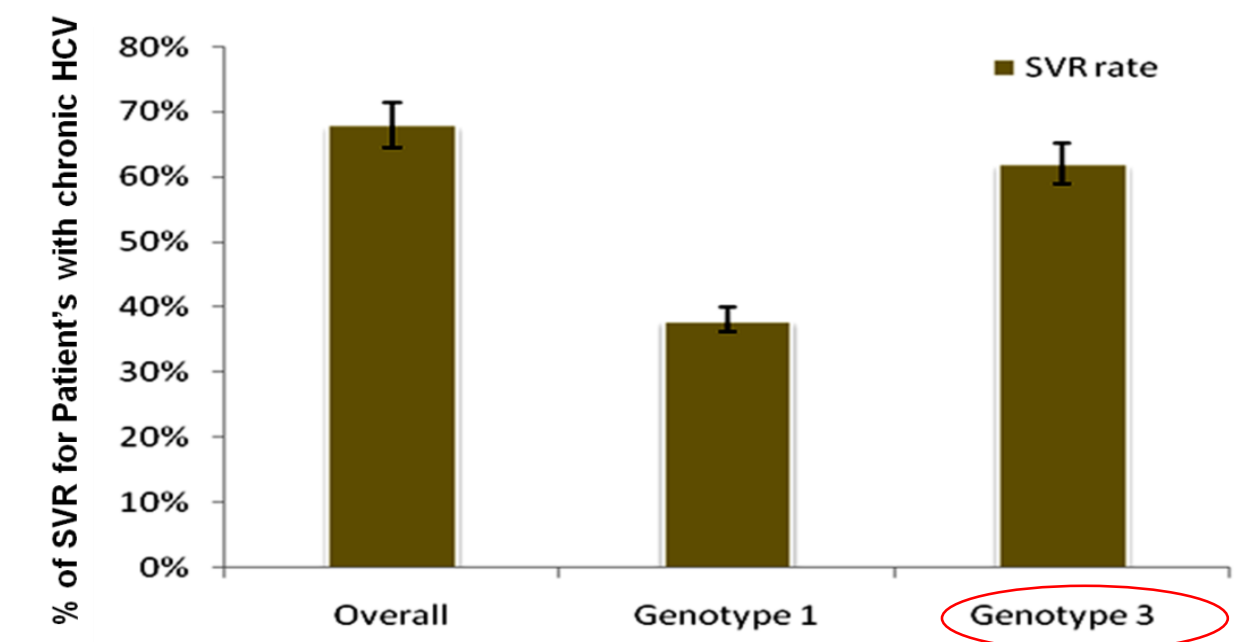

Fig. 2a: SVR rates in the total study population based on HCV genotypes

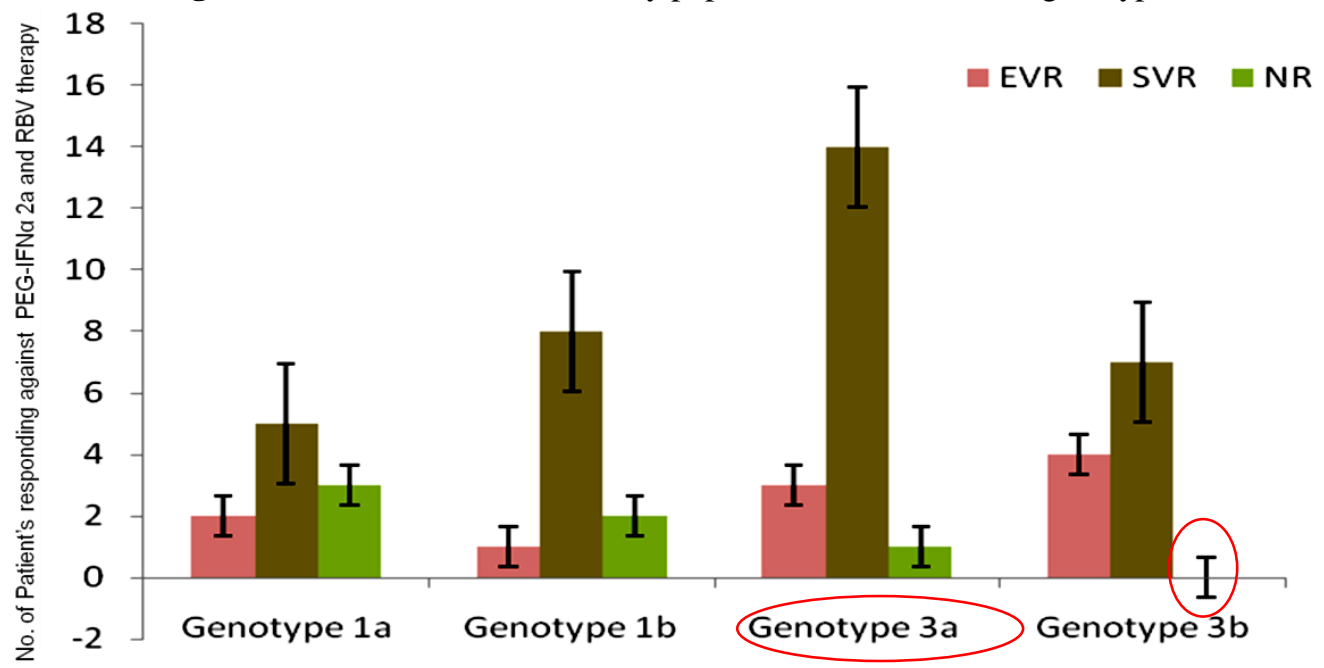

Fig. 2b: Graph showing the virological response stratified by treatment and genotype. With the genotype subtype on X-axis and no of patients with EVR, SVR and Non Responders on Y-axis

\subsection{Predisposing factor associated with SVR}

34 out of $50(68 \%)$ patients treated with PEG-IFN $\alpha$ 2a and RBV achieving the SVR, neither gender, HCV subtype, pretreatment normalized AST, ALT, normalized hematological values nor therapy duration ( $24 \mathrm{wk}$ and $48 \mathrm{wk}$ ) were found to be associated with treatment outcome. Only AST $(\mathrm{p}=0.05 \%$ ) was found significantly associated with SVR (Table 3) 
Table 3: Mean and $p$ value of overall patients with regard to their haematological parameters and serum enzymatic activities for positive and negative SVR against HCV genotypes

\begin{tabular}{|c|c|c|c|c|c|}
\hline & \multicolumn{2}{|c|}{ Positive SVR (12/22) } & \multicolumn{2}{|c|}{ Negative SVR (6/10) } & \multirow[b]{2}{*}{$P$ Value } \\
\hline & $\begin{array}{c}\text { Genotype } 1 \\
(n=13)\end{array}$ & Genotype $3(n=21)$ & $\begin{array}{c}\text { Genotype } 1 \\
(n=8)\end{array}$ & $\begin{array}{c}\text { Genotype } 3 \\
(n=8)\end{array}$ & \\
\hline $\begin{array}{c}\text { Gender } \\
\text { (Female/Male) }\end{array}$ & $(5 / 8)$ & $(7 / 14)$ & $(3 / 5)$ & $(3 / 5)$ & $0.30^{\mathrm{a}}$ \\
\hline $\begin{array}{l}\text { HCV Subtype } \\
(\mathrm{a} / \mathrm{b})\end{array}$ & $(5 / 8)$ & $(14 / 7)$ & $(5 / 3)$ & $(4 / 4)$ & $0.96^{\mathrm{a}}$ \\
\hline $\begin{array}{c}\text { AST-N } \\
(\text { mean } \pm \text { SD })\end{array}$ & $56.7 \pm 0.74$ & $40.76 \pm 0.04$ & $44.8 \pm 0.27$ & $39.5 \pm 0$ & $0.05^{\mathrm{b}}$ \\
\hline $\begin{array}{c}\text { ALT-N } \\
(\text { mean } \pm \text { SD) }\end{array}$ & $75.5 \pm 0.19$ & $56.7 \pm 0.11$ & $53 \pm 0$ & $37.5 \pm 0$ & $0.9^{\mathrm{b}}$ \\
\hline $\begin{array}{c}\text { ALP-N } \\
(\text { mean } \pm \text { SD })\end{array}$ & $107 \pm 0.12$ & $97.6 \pm 3.97$ & $107.1 \pm 0.15$ & $122.5 \pm 0$ & $0.91^{\mathrm{b}}$ \\
\hline $\begin{array}{c}\mathrm{Hb}-\mathrm{N} \\
(\text { mean } \pm \mathrm{SD})\end{array}$ & $1.13 \pm 0.12$ & $1.15 \pm 0.14$ & $1.21 \pm 0.09$ & $1.34 \pm 0.05$ & $0.91^{\mathrm{b}}$ \\
\hline $\begin{array}{l}\text { Platelet } \times 10^{3} / \mu l \\
(\text { mean } \pm \mathrm{SD})\end{array}$ & $188 \pm 51$ & $192 \pm 48$ & $197 \pm 54$ & $201 \pm 63$ & $0.60^{\mathrm{b}}$ \\
\hline $\begin{array}{l}\mathrm{WBC} \times 10^{3} / \mu 1 \\
(\text { mean } \pm \mathrm{SD})\end{array}$ & $5.98 \pm 1.49$ & $6.15 \pm 1.53$ & $6.87 \pm 1.52$ & $5.98 \pm 1.61$ & $0.06^{\mathrm{b}}$ \\
\hline \multicolumn{6}{|l|}{ Therapy Duration/ regimen (weeks) } \\
\hline 24 & $5(38.46 \%)$ & $9(42.85 \%)$ & $3(37.5 \%)$ & $4(50 \%)$ & \\
\hline 48 & $8(61.53 \%)$ & $12(57.14 \%)$ & $5(62.5 \%)$ & $4(50 \%)$ & \\
\hline \multicolumn{6}{|l|}{ IFN- $\alpha 2 \mathrm{a}($ dose $)$} \\
\hline $\begin{array}{c}24 \text { weeks } \\
(9-21 \mathrm{Bio} / \text { week })\end{array}$ & 0 & 0 & $2(25 \%)$ & $2(25 \%)$ & \\
\hline $\begin{array}{c}24 \text { weeks } \\
(18-42 \text { Bio/week })\end{array}$ & $3(23.07 \%)$ & $8(38.09 \%)$ & $1(12.5 \%)$ & $2(25 \%)$ & \\
\hline $\begin{array}{c}48 \text { weeks } \\
\text { (9-42 Bio/week) }\end{array}$ & $8(61.53 \%)$ & $12(57.14 \%)$ & $4(50 \%)$ & $4(50 \%)$ & \\
\hline $\begin{array}{c}48 \text { weeks } \\
\text { (PEG-IFN- } \alpha 180 \mu \mathrm{g} / \text { week) }\end{array}$ & $2(15.38 \%)$ & $1(4.76 \%)$ & $1(12.5 \%)$ & 0 & \\
\hline
\end{tabular}

$\mathrm{a}=$ Fischer's Exact Test, $\mathrm{b}=$ Wilcoxon Mann- Whitney U Test

\section{DISCUSSION}

Virological response kinetics during therapy has emerged as important prognostic factors for the treatment of patients with chronic HCV infection. Absence of EVR at week 12 during therapy is the negative predator for non response to treatment. Patients with RVR defined as undetectable HCV RNA at week 4 of combination therapy have a high probability of achieving SVR. Conversely those without an RVR have considerably lower SVR rates and it is regarded as the most important predictor for SVR.The recommended treatment for patients with hepatitis C genotype 1 is PEG-IFN $\alpha 2$ a and RBV for 48 weeks. Such treatment has yielded overall SVR rates of $45 \%-55 \%$ in randomized control phase III clinical trials [21]. However, the treatment responses are not uniform across all populations and are dependent on various viral and host factors. In patients with genotype 1 higher SVR rates are obtained with 48 weeks than with 24 weeks treatment [20]. In the present study, we have observed that males had a better SVR and EVR as compared to females in both the genotypes (genotype 1 and genotype 3 ) and among the non responders there were less males as compared to females. It was seen that there were less females who showed EVR and SVR as compared to males. There were more females among the non responders as compared to males. Hence males had a better prognosis as compared to females under both the genotypes (genotype 1 and genotype 3 ).

\section{CONCLUSION}

Our study with reference to previous studies have demonstrated that EVR, RVR, NR and most importantly SVR are important factors for the achievement of complete virological response against HCV genotypes and subtypes. The study also suggests that males have greater chance of achieving SVR as compared to the females in against the combination therapy for HCV genotype 1 and genotype 3 .

Acknowledgement: Shaik Iqbal Ahmed, Center for Liver Research and Diagnostics, Deccan College of Medical Sciences and Allied Hospitals, Kanchanbagh, Hyderabad-500 058, AP, INDIA.

Conflict of interest: The authors declares that they don't have any conflict of interest 


\section{REFERENCES}

[1] National Institutes of Health Consensus Development Conference Statement: Management of hepatitis C 2002. Gastroenterology 123: (June 10-12, 2002), 2082-2099.

[2] Verna EC, Brown RS, Hepatitis C virus and liver transplantation. Clin Liver Dis 10, 2006, 919-940.

[3] Hofmann WP, Herrmann E, Sarrazin C, Zeuzem S, Ribavirin mode of action in chronic hepatitis C: From clinical use back to molecular mechanisms. Liver Int 28, 2008, 1332-1343.

[4] Feld JJ, Hoofnagle JH, Mechanism of action of interferon and ribavirin in treatment of hepatitis C. Nature, 436, 2005, 967-972.

[5] Mangia A, Santoro R, Minerva N, Ricci GL, Carretta V, et al., Peginterferon alfa-2b and ribavirin for 12 vs. 24 weeks in HCV genotype 2 or 3. N Engl J Med 352, 2005, 2609-2617.

[6] Shiffman ML, Suter F, Bacon BR, Nelson D, Harley H, et al., Peginterferon alfa-2a and ribavirin for 16 or 24 weeks in HCV genotype 2 or 3. N Engl J Med 357, 2007, 124-134.

[7] Yu ML, Dai CY, Huang JF, Hou NJ, Lee LP, et al., A randomised study of peginterferon and ribavirin for 16 versus 24 weeks in patients with genotype 2 chronic hepatitis C. Gut 56,2007, 553-559.

[8] Zeuzem S Heterogeneous virologic response rates to interferon-based therapy in patients with chronic hepatitis C: who responds less well? Ann Intern Med 140, 2007, 370-381.

[9] Katze MG, He Y, Gale M, Viruses and interferon: a fight for supremacy. Nat Rev Immunol 2, $2007,675-687$.

[10] Chisari FV, Unscrambling hepatitis C virus-host interactions. Nat 436, 2005, 930-932.

[11] Davis GL, Lau JY. Factors predictive of a beneficial response to therapy of hepatitis C. Hepatol, 1997, 26, 122S-127S.

[12] Chemello L, Bonetti P, Cavalletto L, Talato F, Donadon V, Casarin P, Belussi F, Frezza M, Noventa F, Pontisso P, Randomized trial comparing three different regimens of alpha-2a-interferon in chronic hepatitis $\mathrm{C}$. The TriVeneto Viral Hepatitis Group. Hepatol, 22, 1995, 700-706.

[13] Martinot-Peignoux M, Marcellin P, Pouteau M, Castelnau C, Boyer N, Poliquin M, Degott C, Descombes I, Le B, Milotova V, Pretreatment serum hepatitis $\mathrm{C}$ virus RNA levels and hepatitis $\mathrm{C}$ virus genotype are the main and independent prognostic factors of sustained response to interferon alfa therapy in chronic hepatitis C. Hepatol, 22,1995, 1050-1056.

[14] Lindsay KL, Trepo C, Heintges T, Shiffman ML, Gordon SC, Hoefs JC, Schiff ER, Goodman ZD, Laughlin M, Yao R, Albrecht $\mathrm{JK}$, A randomized, double-blind trial comparing pegylated interferon alfa-2b to interferon alfa-2b as initial treatment for chronic hepatitis C. Hepatol, 34, 2001, 395-403.

[15] Zeuzem S, Feinman SV, Rasenack J, Heathcote EJ, Lai MY, Gane E, O'Grady J, Reichen J, Diago M, Lin A, Hoffman J, Brunda MJ, Peginterferon alfa-2a in patients with chronic hepatitis C. N Engl J Med, 343, 2001,1666-1672.

[16] McHutchison JG, Gordon SC, Schiff ER, Shiffman ML, Lee WM, Rustgi VK, Goodman ZD, Ling MH, Cort S, Albrecht JK., Interferon alfa-2b alone or in combination with ribavirin as initial treatment for chronic hepatitis C. Hepatitis Interventional Therapy Group. N Engl J Med, 339, 1998, 1485-1492.

[17] Reichard O, Norkrans G, Fryden A, Braconier JH, Sonnerborg A, Weiland O., Randomised, double-blind, placebo-controlled trial of interferon alpha-2b with and without ribavirin for chronic hepatitis C. The Swedish Study Group. Lancet, 351,1998, 83-87.

[18] Fried MW, Shiffman ML, Reddy KR, Smith C, Marinos G, Goncales FL, Jr, Haussinger D, Diago M, Carosi G, Dhumeaux D, Craxi A, Lin A, Hoffman J, J Yu, Peginterferon alfa-2a plus ribavirin for chronic hepatitis C virus infection. N Engl J Med, 347 , 2002, 975-982.

[19] Manns MP, McHutchison JG, Gordon SC, Rustgi VK, Shiffman M, Reindollar R, Goodman ZD, Koury K, Ling M, Albrecht JK, Peginterferon alfa-2b plus ribavirin compared with interferon alfa-2b plus ribavirin for initial treatment of chronic hepatitis $\mathrm{C}$ : $\mathrm{a}$ randomised trial. Lancet, 358, 2001, 958-965.

[20] Michael WF, Mitchell LS, K. Rajender R, Coleman S, George M, Fernando L. Gonçales, J, Dieter H, Moises D, Giampiero C, Daniel D, Antonio C, Amy L, Joseph H and Jian Y, Peginterferon Alfa-2a plus Ribavirin for Chronic Hepatitis C Virus Infection. N Engl J Med, 347, 2002, 975-982.

[21] Davis GL, Lau JY. Factors predictive of a beneficial response to therapy of hepatitis C. Hepatol, 1997, 26: 122S-127S. 